\title{
PERBAIKAN SIFAT FISIK DAN REAKTIFITAS FLY ASH SEBAGAI CEMENTITIOUS PADA BETON
}

\section{Improvement of The Physical Properties and Reactivity of Fly Ash As Cementitious On Concrete}

\author{
Erwin Rommel ${ }^{1}$, Dini Kurniawati², Arman Putra Pradibta ${ }^{3}$ \\ 1,2,3 Jurusan Teknik Sipil Fakultas Teknik - Universitas Muhammadiyah Malang \\ Alamat korespondensi : Jalan Raya Tlogomas 246 Malang 65144 \\ email : erwin67pro@yahoo.com
}

\begin{abstract}
Variety of materials researchs is curently underway to develop environmentally friendly concrete is very varied in order to meet the demands of higher cement production. One way is to replace some of the cement with the rest of coal burning PLTU or commonly known as fly ash. Purpose of this study was to determine the effort to improve the physical and chemical properties of fly ash as a partial cement replacement material and influence the reactivity of fly ash has improved by incubating the silica synthesis. The physical examination, fly ash decreased in term of quality and fineness increase in the adsorption of the water content. The chemical test showed that a decline in the percentage of the elements Si and Al but an increase in elemental Fe. It also affects the content of the main compound $\mathrm{SiO} 2$ and Mullite are dominated by $77-80 \%$ fly ash decreased after a treatment process. Reactivity test using XRD found that fly ash has decreased the amount of 3,47\% amorphous structure after experiencing the treatment. Fly ash that would be dominated by the reactive silica is a form of amorphous silica, is because the contact surface af amorphous silica is greater than crystalline. This reduction causes no more reactive fly ash after going through the process of treatment and no better used as a partial replacement for cement in concrete.
\end{abstract}

Keyword : fly ash, environmentally friendly concrete, and synthesis

\begin{abstract}
Abstrak
Teknologi bahan dan teknik untuk mengembangkan beton ramah lingkungan sangat bervariatif guna menjawab tuntutan produksi semen yang semakin tinggi. Salah satu caranya ialah mengganti sebagian semen dengan sisa pembakaran batubara dari PLTU atau yang biasa disebut fly ash. Tujuan dari penelitian ini adalah untuk mengetahui upaya memperbaiki sifat fisik dan kimia dari fly ash sebagai material pengganti sebagian semen serta pengaruh reaktifitas dari fly ash yang telah mengalami perbaikan dengan pensintesisan silika. Hasil pemeriksaan fisik, fly ash mengalami penurunan dalam segi kualitas kehalusan dan mengalami kenaikan dalam penyerapan kadar air setelah mengalami proses treatment.Hasil pemeriksaan kimia menunjukkan bahwa terjadi penurunan persentase pada unsur Si dan $\mathrm{Al}$ akan tetapi mengalami peningkatan pada unsur Fe. Hal tersebut juga berpengaruh terhadap kandungan senyawa utama $\mathrm{SiO}_{2}$ dan $\mathrm{Al}_{6} \mathrm{Si}_{2} \mathrm{O}_{13}$ (Mullite) yang mendominasi fly ash sebesar $77-80 \%$ mengalami penurunan setelah mengalami proses treatment. Hasil uji reaktifitas dengan menggunakan XRD didapatkan bahwa fly ash mengalami penurunan jumlah struktur amorf sebesar 3,47 \% setelah mengalami proses treatment. Penurunan ini menyebabkan fly ash tidak lebih reaktif setelah melalui proses treatment dan tidak lebih baik digunakan sebagai bahan pengganti sebagian semen dalam beton secara keseluruhan.
\end{abstract}

Kata Kunci : fly-ash, beton ramah lingkungan, sintesis

\section{PENDAHULUAN}

Perkembangan ekonomi dunia yang semakin pesat saat ini membuat bangunan berbahan beton tumbuh di banyak tempat sehingga produksi beton pun meningkat jumlahnya secara signifikan. Produksi beton identik dengan 'merusak' lingkungan semata mulai dari proses menggali batu kapur, proses pembakarannya, emisinya, dsb. Produksi semen pun dinyatakan sebagai penyumbang karbon dioksida terbesar urutan dua dunia dan menyumbang tujuh persen setelah pembangkit listrik. Oleh sebab itu, 
perlu senantiasa dikembangkan beton ramah lingkungan sehingga pembangunan tidak perlu berhenti demi lingkungan (Hardjito, 2010).

Pembuatan beton dengan komposisi bahan pengganti semen yang makin besar akan memberikan pengurangan efek rumah kaca (pelepasan gas $\mathrm{CO}$ ke udara bebas makin berkurang) (Nashir, 2009). Pemberian bahan pozzolan sebagai salah satu material yang bisa menggantikan semen akan berpengaruh untuk mengatasi permasalahan lingkungan yakni pemanasan global. Pozzolan yang baik harus memiliki sifat yang mirip dengan material semen dengan unsur silika amorf yang dominan. Untuk itu perlu dilakukan proses perbaikan dari bahan pozzolan, salah satunya dengan cara melakukan polimerisasi silika pada bahan pozzolan tersebut.

Perubahan mikrostruktur dari bahan pozzolan akan mempengaruhi sifat kimia dan fisik dari bahan pozzolan tersebut (Pengthamkeerati, et al, 2008). Penelitian ini menjadi penting agar diperoleh bahan pengganti yang tepat tanpa mengurangi kualitas dan fungsi dari material semen yang akan digantikan, sehingga pemakain semen dapat dikurangi dan efek kerusakan lingkungan akibat proses pembuatan semen menjadi dapat dikendalikan dan dikurangi. Pemberian komposisi yang tepat pada material pozzolan terhadap beton juga perlu, karena tidak serta merta bahan pozzolanic tersebut dapat menggantikan semen secara keseluruhan.

Dari penelitian ini diharapkan untuk dapat mengetahui bagaimana upaya untuk perbaikan sifat fisik dan kimia dari abu terbang (fly ash) sebagai material pengganti semen. Serta untuk mengetahui pengaruh sifat reaktifitas dari material fly ash yang telah diperbaiki dengan proses sintesis silika, serta memperdalam pengetahuan tentang material bahan dan dapat memberi masukan tentang kajian alternatif dalam studi material dan bahan di bidang kontruksi sipil

\section{Referensi Penelitian}

Pemakaian PVA (Pulverized Fuel ash) dan MIRHA (Microwave Insenerated Rice Husk Ash) secara bersama-sama dengan larutan $\mathrm{NaOH}$ dan Sodium Silikat $\left(\mathrm{NaSiO}_{2}\right)$ dapat digunakan untuk menggantikan semen konvensional pada pembuatan beton. Pemakaian 5\% MIRHA pada pembuatan beton dapat menghasilkan kuat tekan paling optimum yakni sebesar 25,30 MPa. Penggunaan sistem perawatan eksternal pada beton (seperti ; steam curing, penguapan dengan suhu tinggi) dapat menghasilkan kekuatan beton yang lebih tinggi mencapai 48,88 MPa (Nurudin dan Darmawan, 2010)

\section{Semen Portland}

Perbedaan sifat jenis semen satu terhadap semen yang lain dapat terjadi karena perbedaan susunan kimia maupun kehalusan butir-butirnya. Karena bahan dasarnya terdiri dari bahan-bahan yang terutama mengandung kapur, silika, alumina dan oksida besi maka bahan-bahan ini menjadi unsur - unsur pokok semennya. Sebagai hasil perubahan susunan kimia yang terjadi diperoleh susunan kimia yang komplek, namun pada semen biasa dapat dilihat sebagaimana pada. Oksida-oksida tersebut berinteraksi satu sama lain untuk membentuk serangkaian produk yang lebih komplek selama proses peleburan (Tjokrodimuljo,1996).

\section{METODE PENELITIAN}

Dilakukan pengujian pada satu bahan pozzolan yaitu pozzolan limbah industri (abu terbang). Tahap awal dilakukan pemeriksaan fisik yang meliputi; berat jenis, kehalusan, serta konsistensi, yang proses tersebut dilaksanakan di Laboratorium Teknologi Beton Universitas Muhammadiyah Malang. Setelah itu di Laboratorium Kimia Universitas Muhammadiyah Malang dilakukan perbaikan dengan melakukan pensitesisan silika yakni menginkubasi bahan pozzolan dengan larutan $\mathrm{NaOH}$ selama 24 jam pada suhu $100^{\circ} \mathrm{C}$ (Pengthamkeerati, et al 2008). Dimana abu terbang tersebut mengalami peningkatan luas permukaan, radius pori dan volume pori, serta mengubah struktur amorf abu terbang menjadi bentuk kristalin. Setelah itu dilakukan pemeriksaan komposisi unsur dan senyawa kimia serta uji reaktifitas bahan pozzolan di Laboratorium Sentral Kimia Fakultas MIPA Universitas Negeri Malang melalui pengujian dengan menggunakan $X$-Ray Difraction (XRD) setelah proses perbaikan bahan pozzolan. 


\section{Alat dan Bahan Penelitian}

Fly ash type F, berasal dari limbah batubara PLTU Tanjung Jati B Jepara. Semen, dalam penelitian kali ini menggunakan Semen Gresik sedangkan larutan $\mathrm{NaOH}$, diperoleh dari Laboratorium Kimia Universitas Muhammadiyah Malang. Dalam penelitian ini digunakan larutan
Natrium hidroksida dengan konsentrasi 5 M. Bahan uji akan diperiksa kandungan senyawa serta tingkat reaktifitasnya menggunakan alat $X$-Ray Diffraction (XRD) Merk Philip Type: Expert Pro dan X-Ray Fluorescence (XRF) Merk PAN Analitical Minipal 4 di Laboratorium Sentral Universitas Negeri Malang.

Adapun diagram alur penelitian sebagai berikut :

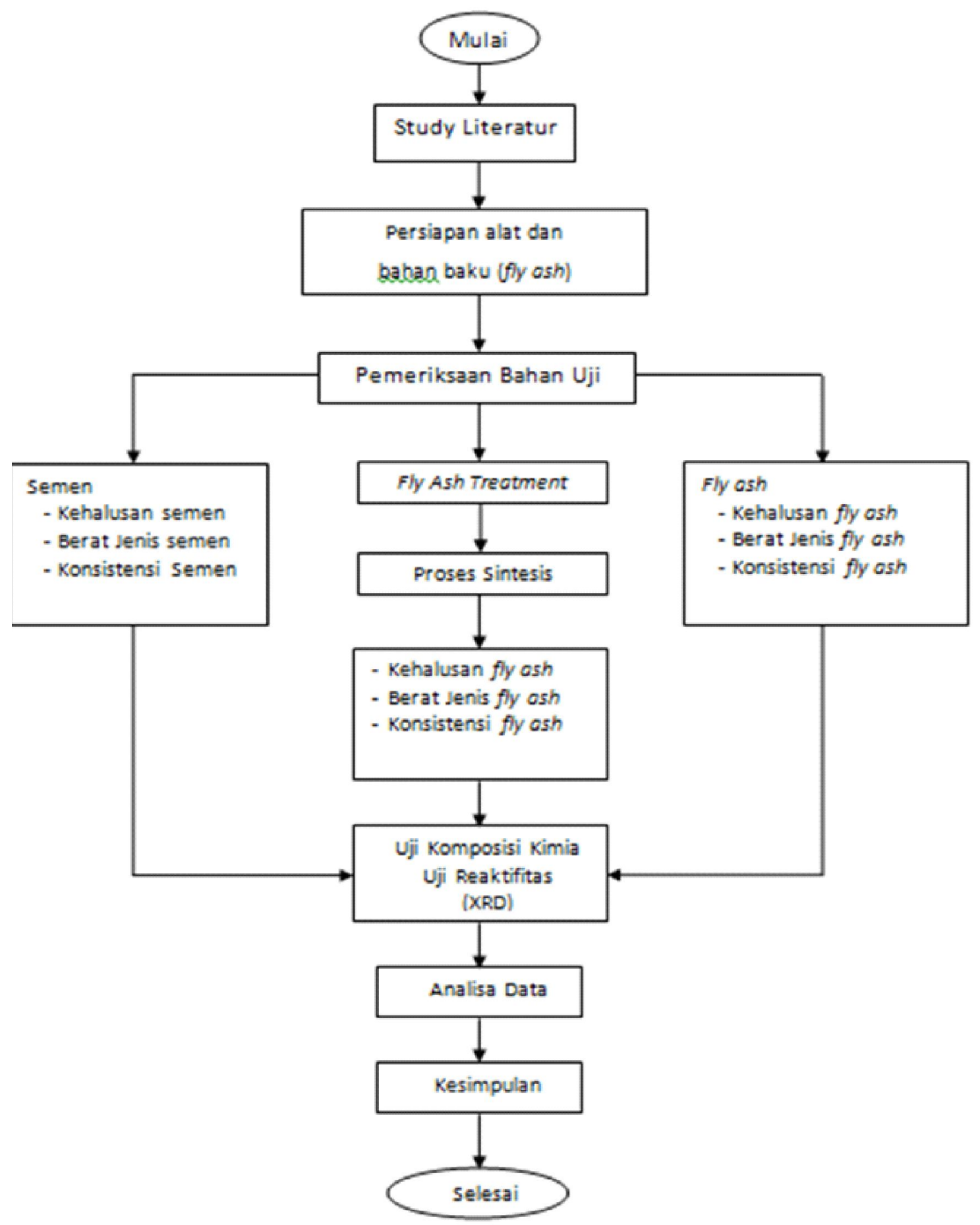

Gambar 1. Gambar Alur Penelitian 


\section{HASIL DAN PEMBAHASAN}

\section{Pemeriksaan Fisik}

Pemeriksaan fisik ini menguji beberapa karakteristik bahan pozolan yang meliputi kehalusan, berat jenis dan konsistensi normal dari material semen portland, fly ash dan fly ash treatment. Adapun hasil dari pemeriksaan fisik, karakteristik bahan dapat dilihat seperti tabel dibawah ini:

Tabel 1. Hasil Pemeriksaan Fisik

\begin{tabular}{cccc}
\hline Karakteristik Bahan & PC & Fly Ash & $\begin{array}{c}\text { FlyAsh } \\
\text { Treatment }\end{array}$ \\
\hline $\begin{array}{c}\text { Kehalusan (\%), tertahan } \\
\text { no 200 }\end{array}$ & 4.9 & 10.1 & 12.84 \\
* Standart kehalusan : & & & \\
$<10 \%$ & & & \\
Berat Jenis $\left(\mathrm{gr} / \mathrm{cm}^{3}\right)$ & 3.17 & 2.625 & 2.60 \\
Konsistensi $(\%)$ & 27 & 28 & 36 \\
\hline
\end{tabular}

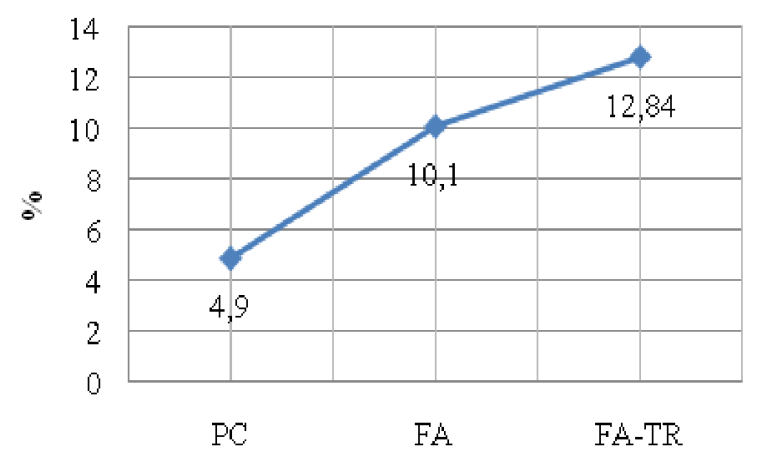

Gambar 2. Kehalusan bahan uji tertahan saringan no. 200

Berdasarkan Gambar 2 pemeriksaan fisik pada bahan uji dapat dilihat bahwa nilai karakteristik kehalusan paling tinggi adalah Portland Cement. Untuk bahan uji fly ash mengalami penurunan yang cukup signifikan, baik fly ash konvensional maupun fly ash treatment. Secara teori, kehalusan fly ash tidak jauh berbeda atau bahkan sama dengan tingkat kehalusan PC. Penurunan fly ash konvensional dikarenakan adanya pengaruh kelembapan. Kehalusan butiran dapat mempengaruhi proses hidrasi dan waktu pengikatan (setting time). Reaksi antara bahan pozolan dan air dimulai dari permukaan butir - butir bahan pozolan, sehingga makin luas permukaan butiran makin cepat proses hidrasinya. Hal ini berarti bahwa, butiran yang halus akan menjadi kuat dan menghasilkan panas hidrasi yang lebih cepat daripada butiran yang lebih kasar. Secara umum, bahan pozzolan yang berbutir halus meningkatkan kohesi pada beton segar dan dapat pula mengurangi bleeding, akan tetapi menambah kecenderungan beton untuk menyusut lebih banyak dan mempermudah terjadinya retak susut. Namun perlu dicatat, bahwa jika butiran terlalu halus, sifat bahan pozzolan akan menjadi kebalikannya, karena terjadi hidrasi awal oleh kelembaban udara. (Tjokrodimuljo,1996).

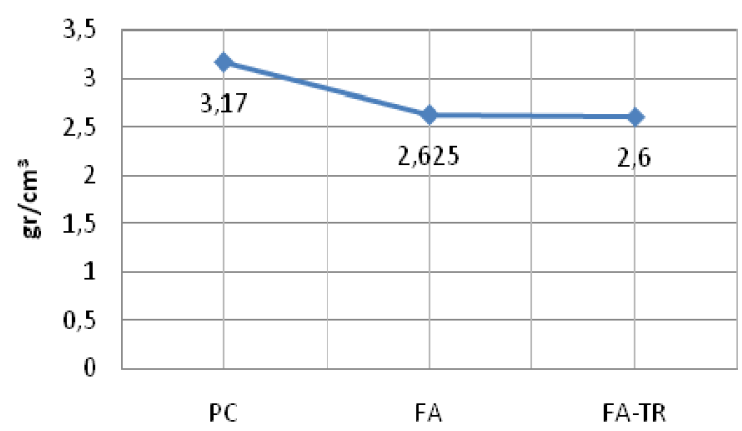

Gambar 3. Berat jenis bahan uji

Dari Gambar 3 dapat dilihat bahwa bahan uji Portland Cement memiliki berat jenis lebih tinggi dibandingkan bahan uji fly ash konvensional danfly ash treatment. Ini dikarenakan unsur - unsur dasar penyusun semen memiliki massa lebih besar daripada fly ash yang memiliki massa lebih ringan, massa fly ash lebih ringan karena struktur penyusun yang dominan ialah debu amorf. Dari Gambar 3 juga dapat dilihat bahwa berat jenis fly ash konvensional dan fly ash treatment tidak berbeda begitu jauh meskipun telah melalui proses sintesis pada fly ash.

Berat jenis bahan pengikat (pozzolan) akan mempengaruhi berat dari beton itu sendiri. Apabila fly ash treatment dapat memenuhi syarat dan digunakan sebagai pengganti Portland cement, baik sebagian ataupun secara keseluruhan maka bisa dipastikan akan merubah berat dari campuran beton itu sendiri. Penggunaan fly ash sebagai bahan pengganti semen dalam campuran beton, dapat mengurangi bobot dari beton secara signifikan.

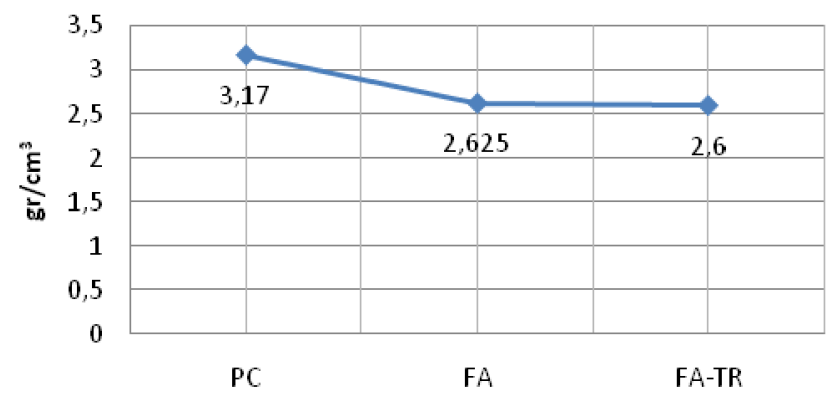

Gambar 4. Konsistensi bahan uji 
Berdasarkan Gambar 4 dapat dilihat bahwa bahan uji Portland Cement memiliki konsistensi paling rendah dibandingkan fly ash konvensional dan fly ash treatment. Ini didasarkan pada sifat dari kedua material yang berbeda dalam kemampuan menyerap air. Fly ash mampu menyerap air lebih banyak dibandingkan Portland Cement, dikarenakan fly ash memiliki struktur amorf lebih tinggi dari semen yang banyak didominasi oleh struktur Kristal.

Konsistensi sendiri ialah suatu kondisi standar yang menunjukkan kebasahan pada semen. Faktor kebasahan atau kadar air terhadap campuran beton juga mempengaruhi fas (faktor air semen) itu sendiri, apabila kadar air terlalu banyak dapat menyebabkan segregation yaitu kecenderungan butir - butir kerikil memisahkan diri dari campuran adukan beton, serta juga dapat menyebabkan air dalam campuran untuk naik ke atas (memisahkan diri) pada beton segar yang baru saja dipadatkan atau yang biasa disebut dengan bleeding (Tjokrodimuljo,1996).

Apabila fly ash treatment digunakan sebagai pengganti bahan semen secara keseluruhan dalam campuran beton, dapat dipastikan penggunaan air akan meningkat dan kualitas beton akan menurun karena kadar air yang terlalu banyak. Pengurangan sebagian kadar semen dan digantikan dengan fly ash akan membuat kualitas campuran beton lebih baik.

\section{Pemeriksaan Kimia}

Pemeriksaan komposisi kimia ini meliputi pengujian X-Ray Difraction (XRD) dari material semen portland, fly ash dan fly ash treatment. Pengujian untuk mengetahui kandungan atau komposisi kimia yang terkandung dalam bahan uji baik dari komposisi unsur dasar maupun komposisi senyawa. Untuk pemeriksaan unsur menggunakan alat X-Ray Fluorescence (XRF), XRF digunakan sebagai tambahan untuk memastikan hasil yang diperoleh XRD.

Hasil pengujian XRD yang dilaksanakan di Laboratorium Sentral Universitas Negeri Malang adalah sebagai berikut:

\begin{tabular}{cccc}
\multicolumn{4}{c}{ Tabel 2. Kandungan Unsur Bahan Uji } \\
Unsur & $\begin{array}{c}\text { Portland } \\
\text { Cement }\end{array}$ & Fly Ash & $\begin{array}{c}\text { Fly Ash } \\
\text { Treatment }\end{array}$ \\
\hline $\mathrm{Al}$ & 2.8 & 13.00 & 11.00 \\
$\mathrm{Si}$ & 10.1 & 28.20 & 26.90 \\
$\mathrm{~S}$ & 1 & 0 & 0.94 \\
$\mathrm{~K}$ & 0.99 & 4.16 & 4.36 \\
$\mathrm{Ca}$ & 72.99 & 12.60 & 12.80 \\
$\mathrm{Ti}$ & 0.48 & 1.95 & 2.04 \\
$\mathrm{~V}$ & 0.03 & 0.11 & 0.12 \\
$\mathrm{Cr}$ & 0.045 & 0.10 & 0.11 \\
$\mathrm{Mn}$ & 0.15 & 0.17 & 0.19 \\
$\mathrm{Fe}$ & 8.27 & 33.80 & 37.40 \\
$\mathrm{Cu}$ & 0.076 & 0.11 & 0.14 \\
$\mathrm{Zn}$ & 0.054 & 0.08 & 0.10 \\
$\mathrm{Sr}$ & 0.21 & 1.10 & 1.30 \\
$\mathrm{Mo}$ & 0.5 & 3.00 & 0 \\
$\mathrm{In}$ & 1.4 & 0 & 0 \\
$\mathrm{Ba}$ & 0.3 & 0.52 & 0.60 \\
$\mathrm{Eu}$ & 0.05 & 0.30 & 0.30 \\
$\mathrm{Yb}$ & 0.29 & 0.00 & 0.03 \\
$\mathrm{Re}$ & 0.23 & 0.20 & 0.30 \\
\hline
\end{tabular}

Sumber: Hasil Penelitian

Dari Tabel 2 hasil kandungan unsur bahan uji dapat divisualisasikan empat unsur dominan melalui Gambar 5 berikut ini :

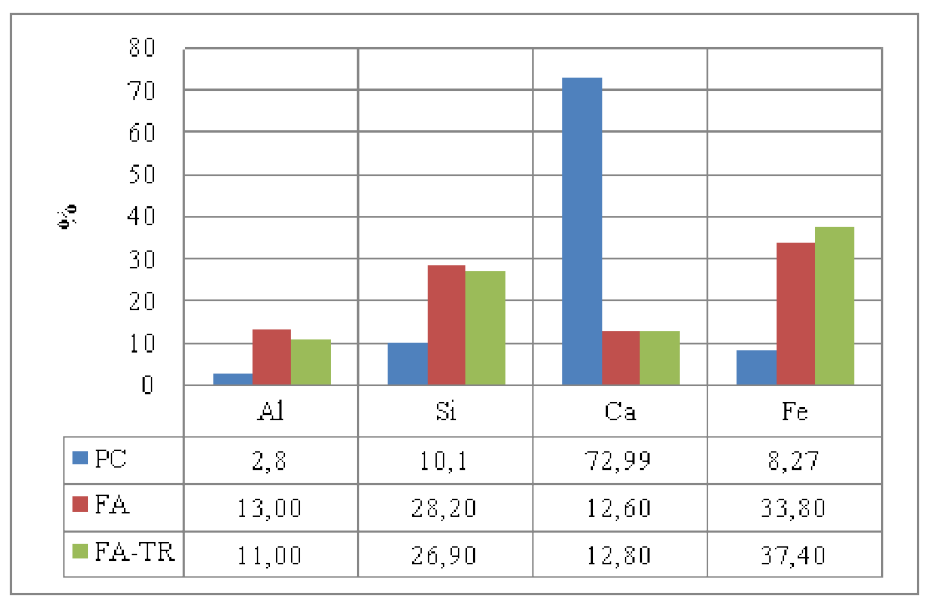

Gambar 5 Empat Unsur yang Dominan 
Berdasarkan Gambar 5 pemeriksaan komposisi unsur kimia, ada empat unsur yang dominan dalam susunan komposisi bahan uji baik yang terdapat dalam PC maupun fly ash yaitu Kalsium (Ca), Silikon (Si), Besi (Fe), dan Aluminium (Al). PC dan Fly ash memiliki kandungan unsur yang sama akan meskipun terdapat nilai persentase yang berbeda antara PC dan fly ash. Kandungan kalsium (Ca) pada PC merupakan unsur yang dominan, dibandingkan kandungan $\mathrm{Ca}$ yang dimiliki oleh fly ash. Untuk kandungan unsur $\mathrm{Al}, \mathrm{Si}$ dan Fe, fly ash lebih dominan dibandingkan dengan PC. Untuk Si dan Fe sendiri merupakan unsur yang paling dominan didalam fly ash dengan persentase total mencapai 60\% (tidak berbeda jauh setelah mengalami proses treatment (Amrhein et al.1996). Untuk unsur Al dan Si pada fly ash mengalami penurunan nilai persentase yang peningkatan sedangkan kandungan $\mathrm{Ca}$ tidak mengalami perubahan meskipun fly ash telah mengalami proses treatment, hal ini dikarenakan perilaku yang berbeda-beda dari kandungan unsur fly ash setelah melalui proses sintesis (Sutarno, Yateman, dan Arief .2009).

Silikon atau Silika merupakan unsur yang penting dalam semen. Sifat silika sendiri yang mengikat gugus hidroksida yang merugikan, membuat beton lebih kuat dan tahan terhadap lingkungan asam. Karena sifat yang demikian inilah, penggunaan fly ash treatment dapat meningkatkan kekuatan beton dan daya tahan terhadap lingkungan asam. Silika dikombinasikan dengan kapur $(\mathrm{Ca})$ menghasilkan material yang bersifat semen. Fly ash dalam penelitian kali ini memiliki komposisi kapur (Ca) yang rendah, baik sebelum atau sesudah proses treatment. Kandungan $\mathrm{Ca}$ yang rendah dapat memperlambat proses hidrasi dengan pozzolan yang terkandung dalam fly ash tersebut. Komposisi silika amorf yang dominan dapat membuat peran Ca dalam reaksi dapat digantikan oleh silika. Aluminium dan besi melengkapi reaksi hidrasi dalam bahan pozzolan, peran Al sendiri dapat meningkatkan ketahanan terhadap korosi, sulfat dan bersama-sama dengan Silika oksida dapat meningkatkan kecepatan pada pengerasan awal pada beton. Besi dalam beton atau besi oksida mempunyai sifat yang sama dengan silika, yaitu sebagai logam yang reaktif. Oksida besi $\left(\mathrm{Fe}_{2} \mathrm{O}_{3}\right)$ berfungsi sebagai penghantar panas dalam pembuatan terak semen. Hasil pengujian kandungan senyawa disajikan pada Tabel 3.

Tabel 3. Kandungan Senyawa Bahan Uji

\begin{tabular}{cccc}
\hline \multirow{2}{*}{ Senyawa } & \multicolumn{3}{c}{ dalam \% } \\
& Portland Cement & Fly Ash & Fly Ash Treatment \\
\hline $\mathrm{SiO}_{2}-$ Quartz & 11.79 & 49.42 & 40.65 \\
$\mathrm{CaO}-\mathrm{Calsium}$ & - & 10.03 & 8.81 \\
$\mathrm{Fe}_{2} \mathrm{O}_{3}-\mathrm{Hematite}$ & 1.69 & 11.28 & 13.99 \\
$\mathrm{Al}_{6} \mathrm{Si}_{2} \mathrm{O}_{13}-\mathrm{Mullite}$ & - & 29.27 & 36.55 \\
$\mathrm{Ca}_{3} \mathrm{SiO}_{5}(\mathrm{C} 3 \mathrm{~S})$ & 83.70 & - & - \\
$\mathrm{CaFe}_{3} \mathrm{O}_{5}$ & 2.83 & - & - \\
\hline
\end{tabular}

Sumber: Hasil Penelitian

Berdasarkan Tabel 4, terdapat empat senyawa yang dominan di dalam $\mathrm{PC}$ yaitu $\mathrm{SiO}_{2}, \mathrm{Ca}_{3} \mathrm{SiO}_{5}$, $\mathrm{Fe}_{2} \mathrm{O}_{3}$ dan $\mathrm{CaFe}_{3} \mathrm{O}_{5}$. Dalam $\mathrm{PC}$, senyawa yang paling dominan ialah $\mathrm{Ca}_{3} \mathrm{SiO}_{5}(\mathrm{C} 3 \mathrm{~S})$ yang dibentuk dari reaksi silika dan kalsium yang merupakan bahan terpenting dalam semen. Melihat pembahasan yang sama sebelumnya, bahwa Silika Oksida $\left(\mathrm{SiO}_{2}\right)$ merupakan senyawa penting yang paling reaktif dalam semen. Silika Oksida $\left(\mathrm{SiO}_{2}\right)$ dan kapur/ kalsium $(\mathrm{CaO})$, membentuk pasta perekat bila dicampur dengan air dan membentuk reaksi hidrasi.

Untuk fly ash, baik fly ash konvensional ataupun fly ash treatment memiliki empat senyawa penyusun yaitu, Silika dioksida / kuarsa $\left(\mathrm{SiO}_{2}\right)$,
Kalsium Oksida $(\mathrm{CaO})$, besi oksida / hematite $\left(\mathrm{Fe}_{2} \mathrm{O}_{3}\right)$ dan Mulite $\left(\mathrm{Al}_{6} \mathrm{Si}_{2} \mathrm{O}_{13}\right)$. Pada fly ash, senyawa yang paling dominan ialah $\mathrm{SiO}_{2}$ dan $\mathrm{Al}_{6} \mathrm{Si}_{2} \mathrm{O}_{13}$, Untuk mulite $\left(\mathrm{Al}_{6} \mathrm{Si}_{2} \mathrm{O}_{13}\right)$ merupakan senyawa yang terbentuk dari reaksi Silika Dioksida dan Alumina. Kedua senyawa ini berperan aktif dalam membentuk ikatan pada bahan pozzolan dikarenakan dua senyawa tersebut paling reaktif bersama dengan Besi oksida yang terkandung didalam kandungan penyusun fly ash. Senyawa Kalsium / kapur $(\mathrm{CaO})$ pada fly ash merupakan senyawa yang kurang dominan bila dibandingkan dengan kandungan kalsium pada semen, kalsium rendah dapat memperlambat proses hidrasi dan memperlemah kekuatan dari campuran beton. 


\section{Pemeriksaan Reaktifitas}

Pemeriksaan tingkat reaktifitas suatu material dapat dilihat dari berapa persentase struktur amorf dan struktur kristalnya. Analisa dapat dilakukan dengan membaca grafik hasil integrasi total difraksi yang merupakan output dari alat X-Ray Difraction $(X R D)$. Dari output tersebut dapat diketahui luas area fasa Amorf dan Kristal material benda uji. Berdasarkan uji XRD didapat luas area fasa Amorf dan Kristal material benda uji. Dengan menggunakan bantuan software highscores, dapat diketahui luas area untuk masing-masing struktur amorf dan kristalinya. Hasil uji luas area fasa amorf dan kristalin disajikan pada Tabel 4.

Tabel 4. Hasil Uji Xrd Untuk Struktur Kristal Dan Amorf

\begin{tabular}{ccccc}
\hline \multirow{2}{*}{ Sampel Uji } & \multicolumn{2}{c}{ Luas area phase } & \multirow{2}{*}{ \% Kristal } & \multirow{2}{*}{ \%Amorf } \\
& Amorf & Kristal & & \\
\hline Fly Ash Treatment & 1298.28 & 809.74 & 38.41 & 61.59 \\
Fly Ash & 1337.19 & 718.08 & 34.94 & 65.06 \\
Portland Cement & 299.58 & 1069.04 & 78.11 & 21.89 \\
\hline
\end{tabular}

Sumber: Hasil Penelitian

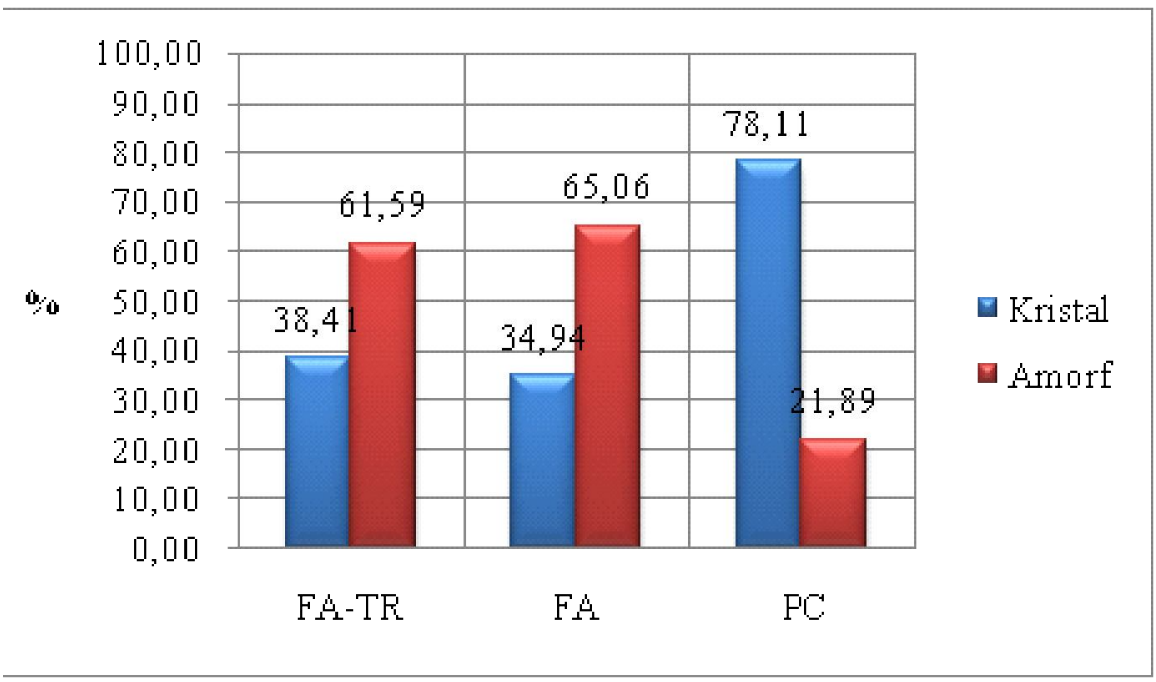

Gambar 6. Persentase kandungan struktur kristal dan amorf

Berdasarkan Gambar 6, didapatkan hasil yang berbeda antara PC dan fly ash. Struktur Kristal merupakan struktur yang memiliki reaktifitas tinggi dalam proses reaksi daripada struktur amorf, ini dikarenakan struktur Kristal memiliki struktur yang lebih stabil dan mudah melakukan ikatan bila bereaksi. Dalam kasus ini jika dipandang dari persentase hasil kristal, Portland Cement memiliki tingkat reaktifitas yang lebih tinggi dibandingkan dengan fly ash. Tingkat reaktifitas PC berbeda dengan fly ash. PC didominasi oleh unsur kalsium (Ca) yang akan sangat reaktif bila berstruktur Kristal sedangkan fly ash sendiri yang didominasi oleh Silikon (Si) lebih dari 70\%, akan reaktif bila berbentuk silika amorf atau bersturktur amorf, ini dikarenakan surface contact area dari silika amorf lebih besar dibandingkan kristalinnya. Silikon merupakan unsur metaloid tetravalensi, bersifat lebih tidak reaktif daripada unsur nonlogam yang tepat berada di atasnya pada tabel periodik, tetapi lebih reaktif daripada germanium, metaloid yang berada di bawahnya pada tabel periodik (Hopcroft,2010). Berdasarkan teori tentang sifat silikon tersebut, silikon berperan besar dalam kereaktifan bahan pozzolan, meskipun dalam kondisi persentase sedikit (dalam semen) mampu untuk mengaktifkan kandungan kalsium dalam semen untuk mengikat dan membentuk bahan perekat untuk beton. Jadi dengan mengubah struktur silika menjadi silika amorf dapat mempercepat reaktifitas ikatan reaksi di dalam bahan pozzolan. Bila melihat perbandingan antara fly ash konvensional dan fly ash treatment berdasarkan Gambar 6, kandungan struktur amorf (dominan silika amorf) menurun setelah melalui proses treatment inkubasi dengan larutan Natrium hidroksida $(\mathrm{NaOH})$. Berdasarkan penelitian yang 
telah dilakukan, dapat ditarik kesimpulan bahwa fly ash tidak lebih reaktif setelah melalui proses treatment, karena struktur amorf silika tidak meningkat setelah melalui proses inkubasi (treatment).

\section{KESIMPULAN DAN SARAN}

Hasil pemeriksaan fisik, fly ash mengalami penurunan dalam segi kualitas kehalusan dan mengalami kenaikan dalam penyerapan kadar air pada konsistensi normal setelah mengalami proses treatment. Hasil pemeriksaan kimia menunjukkan bahwa terjadi penurunan persentase pada unsur Si dan $\mathrm{Al}$, akan tetapi mengalami peningkatan pada unsur $\mathrm{Fe}$ sebesar, Hal tersebut juga berpengaruh terhadap kandungan senyawa utama $\mathrm{SiO}_{2}$ dan $\mathrm{Al}_{6} \mathrm{Si}_{2} \mathrm{O}_{13}$ (Mullite) yang mendominasi fly ash sebesar $77-80 \%$ mengalami penurunan setelah mengalami proses treatment. Hasil uji reaktifitas dengan menggunakan XRD didapatkan bahwa fly ash mengalami penurunan jumlah struktur amorf sebesar 3,47\% setelah mengalami proses treatment, Penurunan ini menyebabkan fly ash tidak lebih reaktif setelah melalui proses treatment dan tidak lebih baik digunakan sebagai bahan pengganti sebagian semen dalam beton secara keseluruhan.

\section{DAFTAR PUSTAKA}

Amrhein C, Haghnia GH, Kim TS, Mosher PA, Gagajena RC, Amanios T, Torre, TDL. 1996, "Synthesis and Properties of Zeolites from Coal Fly Ash", Environment Science Technology Journal Vol 30 No.3 : 735-742.

Badan Standardisasi Nasional, 2002, SNI 03-68632002, Metode pengambilan contoh dan pengujian abu terbang atau pozolan alam sebagai mineral pencampur dalam beton semen portland.

Grolier International, Inc, 2004, Ilmu Pengetahuan Populer Jilid 4 Ilmu Pengetahuan Lingkungan, Kimia dan Fisika, PT Ikrar Mandiriabadi, Jakarta.

Hardjito D ,DR, 2007, Pembangunan Berkelanjutan, Material Beton Ramah lingkungan dan Edukasi Mahasiswa, Seminar Nasional Lingkungan Hidup, Jurusan Teknik Sipil Universitas Kristen Petra, Surabaya
Hopcroft, et al., 2010, "What is the Young's modulus of Silicon?", IEEE Journal of Microelectromechanichal Systems, Vol. 19, No. 2 (229-238) April, University of California at Berkeley.

Nashir, Muhammad dkk, 2009, Pemanfaatan Material Silicafume dan Iron Slag Dalam Pembuatan Beton Berkualitas dan Ramah Lingkungan, Tugas Akhir Tidak Dipublikasikan Jurusan Teknik Sipil Fakultas Teknik Universitas Diponegoro, Semarang.

Nurudin M.F and MS Darmawan, 2010, Compressive Strength and Microstructure Properties of Polymer Concrete Incorporating Pulverized Fuel Ash (PFA) and Microwave Incenerated Rice Husk Ash (MIRHA), Proceeding of International Seminar on Applied technology, Sience and Arts ( $2^{\text {nd }}$ APTECS) December, ITS, Surabaya. 